\title{
Happy \#monthsary babe! Vernacular readings and practices of monthsaries among young couplings on social media
}

\author{
CRYSTAL ABIDIN, National University of Singapore
}

\begin{abstract}
Romantic monthsaries, or monthly commemorations of the date on which a couple first got together, are increasingly practiced by young couples and archived on social media. As a form of visually oriented practice, monthsaries are fraught with vernacular readings, perceptions, and practices. This paper investigates the practice of monthsaries among 'young couplings', which I define as the experiences of young people's partnering practices in their teenage years and/or their initial experience of early partnering regardless of the age of first coupling, in which young couples do not yet have any formal status, are unable to experience domestic living together, and have limited opportunities to be alone and intimate. In the absence of any scholarly precedence and adopting a Grounded Theory approach, this paper is an exploratory study that approaches monthsaries through internet folk knowledge, forum threads and visual displays of monthsaries on Instagram.
\end{abstract}

\section{KEYWORDS}

Monthsary, Coupling, Instagram, Romantic relationships, Courtship rituals, Dating, Social Media

Romantic monthsaries, or monthly commemorations of the date on which a couple first got together, are increasingly practiced by young couples and archived on social media. The 'monthsary' tag is growing by the day on the visually oriented platform Instagram, with over 146,599 posts as of July 2016, in which young couples are publicly archiving mini-milestones in their relationship. Variants of the hashtag - monthaversary $(17,141)$, monthiversary (16,519), monthsaries (757), monthaversery (445), monthsery (342), monthary (318), moniversary (289), and monthsaversary (142) - bring the total number of 'monthsary' posts to over 182,000 as of July 2016. Specifically, I look at 'young coupling', which I define as the experiences of young people's partnering practices in their teenage years and/or their initial experience of early partnering regardless of the age of first coupling, in which young couples do not yet have any formal status, are unable to experience domestic living together, and have limited opportunities to be alone and intimate. I use the term 'coupling' with reference to the process of pairing, as two individuals consciously and conscientiously demarcate themselves as a romantic unit and 
curate displays of their relationship through monthsary practices as an emergent form of digital communication on social media. This includes Public Displays of Affection (PDA) on social media, in which couples communicate their love for each other, expressing longing, or making in-jokes to signpost their exclusivity (Mod 2010: 69). In a distinct but similar vein, Jackson et al. (2011: 630) have defined ‘dating' as “a form of courtship [that] encompasses social activities between two people assessing the possibility of deepening the relationship over time”. Where 'dating' is focused on the courtship aspect of the relationship, 'coupling' is interested in the overall progression wherein two individuals come to define themselves as a twosome in domestic and public spaces.

Monthsaries are one form of rituals that are crucial as "dynamic social (re)enactments by which relational partners co-create the identity of a relationship, a shared history, and a pattern of everyday, shared interactions” (Bruess \& Pearson 1997: 28). A recurring practice of monthsaries as a dating ritual is "essential to healthy interpersonal relationships” Pearson et al. (2011: 360, drawing on Baxter 1987, Campbell \& Ponzetti 2007, Oring 1984) if practiced at an appropriate intensity. Monthsaries can also mark the progression of a coupling, which "may take the form of loosely defined stages marked not by deliberate decisions, but by various actions taken by a couple” (Jackson et al. 2011: 630, drawing on Manning \& Smock 2005).

In the absence of any scholarly precedence, albeit drawing on related psychology research on couples' self-presentation on Facebook, this anthropological study is rooted in the practices of Grounded Theory (Glaser 1978) and adopts a three-prong approach. In the first part, I explore vernacular meanings of monthsaries through internet folk knowledge. Drawing on user-generated word banks such as the Merriam-Webster online dictionary and Urban Dictionary, I disentangle collective definitions of the 'monthsary' and its variant neologisms. In the second part, I survey local perceptions of practices of monthsaries among Singaporean couples. Investigating an early forum thread hosted on a Singapore-based internet forum, sgclub.com, in which internet users in Singapore contextualize local readings of the 'monthsary', I analyse how monthsaries are discussed and enacted in the Singapore context. In the third part, I survey the visual displays of monthsaries through dating scripts generated by young microcelebrity (Senft 2008) couples in Singapore. Focusing on Instagram as one of the fastest growing visual social media apps in Singapore (Aw Yeong 2013), I thematically code social scripts portrayed by three young, prolific Singaporean microcelebrity couples, in which monthsaries are archived as couple-branding practices, constituted as events, and framed as relationship milestones. Wherever applicable, pseudonyms are used.

\section{Internet vernacular meanings of the monthsary}

Based on a Google search of user-generated, crowd-source online databases cataloguing vernacular definitions of emergent neologisms and slang, the Merriam-Webster online dictionary and Urban Dictionary present the highest number of variants on the term, 'monthsary'. From the main landing pages in both online dictionaries defining 
'monthsary', I followed related links prompted by the website or examples listed by other users to track variant spellings. With the earliest contributions dating back to August 2006, Merriam-Webster include the variants "monthary", "monthaversary", "monthaversery", and "monthiversary", while the earlier contributions on Urban Dictionary date back to November 2004 and include "monthsaversary” (undefined), "monthaversary", "monthiversary”, "month aniversary" (undefined), "moniversary", and "menthuversary". In this paper, I treat these related neologisms as the collective 'monthsary' and assess their vernacular definitions equally, given that this term has the highest circulation and greatest prominence on both databases and on Instagram.

Broadly speaking, monthsaries are monthly commemorations of an event on the date on which it first occurred, and are most commonly practiced by couples marking small milestones of their dating relationship. Merriam-Webster (2015) defines 'monthsary' as "Monthly celebration especially in love relationships”, and Urban Dictionary (2015a) similar defines it as the time in which "a couple has been together for a month. However, crowd-sourced definitions present more distinct folk definitions as a form of oral tradition (Ong 1982) and knowledge of the monthsary. After initial coding of all dictionary entries listed, I grouped similar user-generated definitions together. These groups underwent axial coding before I developed categories through which monthsaries are defined: minimilestones, cynical brevity, commitment affirmation, exceptional gifting, gendered expectancies, and celebratory excess. In the following sections, I detail each of these themes explicated from key examples.

\section{Mini-milestones}

Monthsaries are mini-milestones for relationships in their very early stages, most often those that are less than a year old. Some internet users distinguish only their first monthsary as an exceptional occasion, such as in Merriam-Webster's (2015) definition as "the date marking when something, such as a relationship... has lasted a month". However, others account for every month leading up to their first relationship anniversary as a significant cumulative achievement, such as the "celebration of an event that occurs on the same date every month prior to one year" (Merriam-Webster 2015) and "a word cute couples use to celebrate each month until their anniversary" (Urban Dictionary 2015b). The description "cute couples” seems to suggest that an audience perceives a pair that celebrates monthsaries as being ideal, precious, or more loving, echoing research by Coyne et al. (2011: 157) on media use in romantic relationships that "higher relationship satisfaction predicted more media use to express affection”. This also reflects a similar study by Saslow et al. (2012: 411) on Facebook images that "individuals who posted dyadic profile pictures on Facebook reported feeling more satisfied with their relationships and close[r] to their partners”.

\section{Cynical brevity}

Monthsaries are also noted for their cynical brevity, under the insinuation that young coupling is precarious due to a lack of loyalty and commitment. One definition in Urban 
Dictionary (2015a) postulates that monthsaries are "used rather than anniversary coz couples are playas and bitches enough to be together for only a meagre amount of time", wherein "playas" and "bitches" are slang words popularized by hip-hop culture referring to people who are unable to commit long-term to a monogamous partner, but who instead engage in a series of short-term relationships. Elsewhere (Urban Dictionary 2015d), monthsaries are evaluated as monthly celebrations for couples who "have not been together long enough to celebrate a real anniversary”, suggesting that most young couples will not reach anniversaries yet wish to partake in the 'grownup' experience of a milestone celebration. This cynicism contrasts research on Facebook use during romantic relationships that argues that public assurances of a relationship - such as "Facebook official" status updates - are "one of the primary means" through which "uncertainty" about the "initial stages of relationship formation" is reduced (Fox et al. 2013: 771). Rather, most vernacular readings of monthsaries note them as "usually celebrated by younger couples who are grateful their relationship has even survived a month" (Urban Dictionary 2015c), reinforcing the normative brevity and precarity of young relationships.

\section{Commitment affirmation}

On a brighter note, monthsaries are positively acknowledged as events in which couples can affirm their commitment towards each other. As a "monthly anniversary" (Urban Dictionary 2015e), monthsaries are "a measure of commitment between anniversaries" (Merriam-Webster 2015), especially among "newbie relationships” (Merriam-Webster 2015). Monthsaries memorialize the start of a couple's relationship as a "special event" to be "celebrated" (Merriam-Webster 2015). They also acknowledge the mutuality of the relationship as a social contract marked by one party inviting another into a coupling (Urban Dictionary 2015c), thus favouring the "official” (Urban Dictionary 2015c) start date of the coupling over other ambiguous and fraught beginnings. Similar to that of the mini-milestone discussed earlier, the commitment affirmation in monthsary celebrations also extends to a cumulative achievement in sustaining the couple as a unit across "consecutive month(s)" (Urban Dictionary 2015b). Although social media platforms are usually utilized by couples to communicate inwardly with each other (Rueda et al. 2015: 429), in this instance, couples seem to display monthsaries on the internet as a way to outwardly display their affection. This echoes Fox \& Warber's (2013: 3) research on romantic relationship development on Facebook in which "Facebook official" status updates reflected a couple’s “commitment, intensity, and social response” to each other. As such, monthsaries are one form of PDA that heighten a sense of "possession and territory”, and the constant re-affirmation of commitment is used to "configure a couple's superiority” (Mod 2010: 61).

\section{Exceptional gifting}

Monthsaries tend to serve as occasions at which gifting becomes an expected ritual with exceptional gifts (Bailey 1989, Jackson et al. 2011: 634). Early anthropological research by Levi-Strauss (1969) and Malinowski (1922) note that the gestural exchange of gifts functions to develop and maintain a social relationship. While the monthsary itself may 
serve as a communicative gift in which couples publicly display their union and reinforce their commitment to each other, a material gift or shared recreational experience seems crucial to mark the mini-milestone. Monthsaries may be mobilized to account for guilty pleasures such as celebrations with "cake” (Urban Dictionary 2015b). However, they are not merely occasions at which couples have "an excuse" to purchase gifts for a loved one (Urban Dictionary 2015b). While gifting is expected during monthsaries, the value of the gift - whether gauged by monetary value, personal effort, social symbolism, or otherwise - has to be exceptional and more commemorative than the routine and mundane gifting in the daily repertoire of a courtship. Thus while the act of gifting during monthsaries is expected, the value of the action has to be exceptional, wherein couples invest in more distinctive activities or more lavish expenditures (Urban Dictionary 2015b). Such monthsary gifting is expected to be "reciprocal" (Urban Dictionary 2015c) in which both partners demonstrate equal effort or bring a gift of equal value, rather than "altruistic" (Gouldner 1960) in which partners gift sacrificially without anticipation or expectation of any returns.

\section{Gendered expectancies}

In other instances, the monthsary practices of exceptional gifting and coupling commemorations may be non-reciprocal; this is not necessarily altruistic (Gouldner 1960) but rather, a failure to reciprocate an expected exchange. Vernacular accounts express that monthsaries are disproportionately an expectancy harboured by the woman - echoing accounts by Areni et al. 1998 and Greer \& Buss 1994 in their studies of gifting practices between couples - in normatively heterosexual relationships. Jackson et al. (2011: 634) similarly note that "women view themselves as recipients of gifts rather than as gift givers”. In one account of how monthsaries play out, a user on Urban Dictionary (2015d) catalogues an exchange as such:

[woman]: Happy 3 month moniversary, Joe! Only nine more months until our one year anniversary

[man]: Uh, gee, thanks. Was I supposed to get you a card or something?

In this example, the unequal importance placed on the commemoration of monthsaries is evident in the non-reciprocal tone of excitement between the woman and the man. This is underscored by the woman's apparent enthusiasm and vivacious count down to their "one year anniversary", that was quenched by the man's understated and blasé response, "Uh, gee, thanks.” Furthermore, he displays his unawareness of monthsary etiquette by asking if he was "supposed to get [her] a card or something", thus signposting a budding cognizance of unspoken rules of dating in their coupling. Jackson et al. (2011: 632), drawing on Bailey (1989), identify gifting practices in traditional dating rituals as "the economic exploitation of men”. Such gendered expectations of exceptional gifting are reiterated in another example sentence (Urban Dictionary 2015b), in which a presumably 
female partner laments: “Ted, where the HELL IS MY MONTHIVERSARY PRESENT, you cheap bastard??”

Additionally, the responsibility of remembering and thus actively commemorating monthsaries seems to be an expectation female partners have of male partners, as evidenced in vernacular definitions such as "The day the beotch never lets you forget" (Urban Dictionary 2015b), and "Something that she might bitch at you for forgetting." (Urban Dictionary 2015b). In each of these, the subtext is that it is typically the male partners who will fail to reciprocate expectancies of monthsaries, much to the displeasure and anger from female partners. This demonstrates that monthsaries enact a normative dating script in which the quality of dates are evaluated. Curiously, none of the dictionary entries feature overtly homosexual references or other relationship structures such as polygamy, supporting the notion that monthsaries are a highly gendered and heteronormative practice.

\section{Celebratory excess}

Lastly, monthsaries are marked by a sense of celebratory excess, in that the scale of commemoration practices exceeds the actual event being memorialized. The derision towards monthsaries is expressed in definitions such as "A ritual annoying to some" (Urban Dictionary 2015d) and "Ani=Year, Month=Month therefore im stupid and came up with this word” (Urban Dictionary 2015b). Others note that monthsaries are an unnecessary extravagance wherein "Another walk of life [is] celebrated by a useless holiday” (Urban Dictionary 2015b).

Most notably, the disdain towards monthsaries seems rooted in a dislike for PDA in which couples “express undying love” (Urban Dictionary 2015b), show “mindless infatuation” (Urban Dictionary 2015b), or are "overzealous about a new relationship” (Urban Dictionary 2015b). In his work on the impact of Facebook rituals on romantic relationships, Mod (2010) asserts that couples post PDA to solicit the public into being “a witness to their love affair” (2010: 69-70), which bystanders perceive as irritating, unnatural, and "falsif[ying]" a relationship (2010: 69). In other words, the self-celebratory and self-branding act of carefully archiving and displaying monthsaries on social media can be read as competition between couples or the need for public affirmation of a coupling, such as in one user's definition of monthsaries as "A contest to see how many more months you can stand one another than another couple” (Urban Dictionary 2015b).

\section{Readings of the monthsary in Singapore}

Turning to a Singaporean example to contextualize local readings of monthsaries, I analyse one of the earliest comment thread on monthsaries, hosted on a popular public forum, sgclub.com. This forum was chosen because it brands itself as a portal for "relationships, self-improvement, love and dating" (sgclub.com 2015b), is among the oldest internet forums in Singapore having debut in 2004 (sgclub.com 2015b), and 
contains a thread with a highly focused discussion on monthsaries. The website includes other categories such as "Lifestyle Events”, “Arts \& Culture”, “Movies”, "Humour”, "Educational", and "Lifestyle", and claims to be "one of the top 10 sites in Singapore for online communities" with an average of 730,000 unique visitors monthly accumulating approximately 3.5 million pageviews (sgclub.com 2015b). Although no information on its reader demographics is currently made public, the website claims that $70 \%$ of its traffic is from search engines (sgclub.com 2015b).

On the forum thread titled "Monthsary", users in Singapore shared their thoughts on couples who celebrate monthsaries. Comments archived were dated between March and May 2012, and can be read as a snapshot of how monthsaries were understood among a small group of local users. 25 responses were offered to this initial post:

One my colleagues couldn't hide her disappointment. Apparently, her boyfriend forgot that today is their monthsary. I don't know how long they have been together. I have nothing against couples who 'celebrate' their monthsary but personally I don't think I will give such importance to that particular date every month. What are your thoughts on this? (sgclub.com 2015a)

Upon axial coding, each of these 25 responses correspond to my earlier taxonomy of monthsaries derived from my thematic analysis of dictionary entries as follows: Minimilestones (6), Cynical brevity (2), Commitment affirmation (3), Exceptional gifting (2), Gendered expectancies (4), Celebratory excess (8). Unlike the earlier section in which I relied on user-generated dictionary entries to investigate folk definitions of monthsaries, in this section, I specify how a group of Singapore users perceive and practice monthsaries.

Mini-milestones are only significant to early couplings, first couplings, or at memorable intervals

For some forum commentators, monthsaries are commemorated as milestones in the early stages of a coupling, after which couples celebrate anniversaries instead. One user shared that she used to be "quite concerned" over monthsaries, but felt it lost importance as her relationship progressed. Another user shared that she and her boyfriend actively celebrated monthsaries for the first six months, but after that found there was "no point" in such frequent celebrations. In place of monthsary date nights or outings, they now send each other text messages wishing each other "happy monthsary”. Monthsaries thus seem to be of more importance when early couplings are attempting to construct a "shared understanding of experiences, symbolize intimacy, and create a shared sense of the relationship (Pearson et al. 2011: 360, Oring 1984).

For two other users, monthsaries are significant in their first relationships but not so much in subsequent ones. One user in particular shared that he "didn't have any problem” with celebrating monthsaries in his first relationship because he "thought every couple in the 
world celebrate[d] monthsaries”. With his inexperience and in the absence of other dating scripts, he admitted that he adhered to monthsaries assuming it was the norm. He later revealed that in his following relationships he only celebrated anniversaries.

Two other users specify that monthsaries are acceptable during numerically significant intervals such as when "the number is interesting" as in the case of a " $100^{\text {th" }}$ monthsary. Despite being a multi-cultural society comprising four major ethnic groups, Singaporean Chinese make up the majority of the local population (YourSingapore 1015). In Chinese cultural practice, some numbers deemed auspicious when their homonyms are words with positive meanings (Ang 1997). For instance, the number 7 is valued because the mandarin pinyin " $\mathrm{Q} \overrightarrow{1}$ " represents togetherness. $7^{\text {th }}$ and $77^{\text {th }}$ monthsaries may thus be significant, as well as other numerical permutations such as $17^{\text {th }}$ monthsaries, in which the mandarin pinyin "YiQī" similar represents warm unions. Thus, these selective monthsaries become "homages” to what couples "regard as sacred” (Baxter \& Braithwaite 2006: 262).

For these Singaporean users, monthsaries become "governed by a set of rules" (Jackson et al. 2011: 631, drawing on drawing on Cate \& Llyod 1992, Knox \& Wilson 1981, Waller 1937) between the couple, be it a milestone monthsary after which couples should progress to only celebrating anniversaries, reliance on an assumed dating script, or the selective celebration of exceptional monthsaries.

\section{Cynical brevity is inauspicious and pre-empts precarity}

One Singaporean user noted that monthsaries are "sad thing[s]" as they imply that the coupling is precarious, or that the couple "wouldn't stay together long enough to survive anniversaries". Another user shared that she and her boyfriend used to place "a HUGE importance" on their monthsaries for the first two years since it "reminded" them of how they first met. However, they later "decided to drop the whole thing" because they felt "placing a date/timeline" on their relationship seemed to imply an ultimatum.

\section{Commitment affirmation changes in form as couplings progress}

Three users acknowledged that while monthsaries were important milestones to affirm their commitment to their partners, their practices have evolved as their relationship progressed. One male user shared that he used to "buy [his girlfriend] a flower" every monthsary date night. However, overtime their work schedules impeded regular meet-ups and anniversaries have taken over as their primary commemorative event. Another male user said that while him and his girlfriend "don't really celebrate and keep track of every month", they organize their schedules to "at least" be able to meet in person on their monthsary to spend time together. The third user admits that while she had her boyfriend "sort of celebrate" their monthsaries with a "nice dinner", their birthdays, anniversary, and the date on which they first met each other were more "important" and "must [be] celebrate[d]" as "more meaningful" than their monthsary. These accounts of malleable practices echo Jackson et al.'s (2011: 630-631) review of dating literature in which "flexible yet normative 'scripts"” are a form of "multilevel guides for behaviour". 


\section{Exceptional gifting is unnecessary expenditure}

Two users, both male, identified the gifting practices in monthsaries as unnecessary expenditures. The first male user called it "a waste of money and time", and asked fellow forum users " 1 year later being together see you still want monthsary anot”. By this, he implies that monthsaries are an effortful endeavour, and suggests that couples are unlikely to continue celebrating them after their first anniversary. In support of this sentiment and alluding to the excessive expenditure monthsaries entail, a second male user jokes that he misread the title of the thread as "Monthly salary". In expression of how incredulous he feels towards monthsaries, he admitted that this was his "first time hear[ing] of this terminology", and included the emoticon ("graphological realizations of facial expressions” using keyboard characters; See Zappavigna 2012: 71) "o.o” to underscore his surprise.

\section{Gendered expectancies are a male burden}

Although male users shared some of the earlier positive accounts of monthsaries, three additional male users highlighted the gendered expectancies of monthsaries as a male burden. One user brushed off monthsaries as "boliao", a Hokkien-Singlish (a creole of Singaporean English; See Forbes 1993) vernacular translated from the Mandarin “无聊”, to mean boredom (adjective) or a silly act (noun). In response to earlier accounts of boyfriends who engaged in monthsaries, he sympathizes with the comment "poor bf" [boyfriend]. A second user similar responded with "how can her bf take it?", in relation to earlier accounts of girlfriends expecting increasing frequent surprises to commemorate monthsaries and their relationship. A third user, as if acquainted with a personal bad experience, advised other men to "give and take" by accommodating their partners who wish to celebrate monthsaries. He said to "let it be might as well" to prevent "both face black black”, a Mandarin-Singlish vernacular translated from the Mandarin “脸黑黑”, to mean to be in a foul mood.

A female user later remarked that while she and her husband used to celebrate monthsaries, it was only because he could "accept" the practice for her. Her husband now prefers to celebrate only anniversaries as they are "much [more] special" than monthsaries, and she has decided to go along with him. In response to the post that started the thread, she suggests the original poster tells their colleague "dont be sad" as "some guys dun bother abt the monthsary becos for them is not a special date/day but jus any other normal day". She adds that male partners "will have a hard time rmbing all the special date[s]" and suggests that the woman consults their partner on whether monthsaries are a labour they "can accept [or not]".

\section{Celebratory excess loses meaning from saturation fatigue}


A majority of the thread responses suggest that celebratory excesses cause monthsaries to lose meaning due to saturation fatigue. Monthsaries were deemed too "small" of a "thing" to "worry" about especially since its recurrence causes its significance to erode over time. One user felt monthsaries were an "overkill”, and another candidly painted a slipper slope scenario of monthsaries eventually becoming "weeksar[ies]". Another male user alluded to fatigue from the repetition of monthsaries with a blunt exclamation: "Monthsary? What the fudge?! I will kill myself if I had to go through every month celebrating the day we got together”.

Pearson et al. (2011: 361) note that rituals are "routine behaviors with special associated symbolic meaning for the couple". However, amidst saturation fatigue from the reoccurring obligations of monthsaries, rituals become devoid of "symbolic meaning" and are watered down into mere "routines” (Pearson et al. 2011: 361). Other users opined that monthsaries add to the chore of having "too many special days to celebrate", and demarcated "birthdays" and "anniversaries" as appropriate celebratory milestones. In recognition of the need to reaffirm and celebrate a coupling, users offered that anniversaries were "more than enough", "more meaningful”, and a "big occasion" that warranted “meaningful” investment.

\section{Visual displays of the monthsary}

Having explored how internet folk knowledge discursively constructed the monthsary, and how a group of internet users in Singapore dissected local perceptions and practices of the monthsary, this last section turns to three short case studies of couples who visually enact monthsaries.

The couples were selected from a larger subset of informants in a project investigating public domesticity (Abidin 2015a), in which I adopt personal interviews, content analysis of social media posts, and participant observation in private homes and special occasions such as weddings. In particular, I study how ordinary couples and microcelebrity couples in Singapore negotiate public curation and branding of their relationship, particular hardship such as long distance dating and inter-cultural compatibility, milestones towards marriage such as proposals and engagement shoots, and homemaking and domestic life.

In this paper, each couple is a microcelebrity pair who consistently catalogued their relationship on Instagram for at least three years, and actively curate and publicise the visual displays of their monthsaries. In all instances, the female partner is a microcelebrity Influencer for whom displays of the personal, private, and intimate form the mainstay of social media content in the 'lifestyle' genre to engage with followers and promote advertorials (Abidin 2014). While both female and male partners had public Instagram accounts on which they publicized their monthsary escapades, the female partners had significantly larger followings (between 30,000 and 184,000), while the male partners had smaller followings (between 150 and 24,000) usually comprising users who also followed their female partners on Instagram. Although only one of the three male partners 
featured has himself become a microcelebrity Influencer, this trajectory is not uncommon among other microcelebrity couples in Singapore in which female Influencers groom their male partners into microcelebrity. Thus, while the Instagram accounts of male partners are (initially) more oriented towards personal friends, the accounts of female partners are (intentionally) directed at large unknown audiences who periodically demonstrate envy of and aspirational towards the Influencer.

Consequently, these microcelebrity couples are unlike ordinary couples investigated in psychology studies on Facebook, in which partners are more likely to "demonstrate similarity on technology behaviors and preferences (Papp et al. 2012: 88), to upload "dyadic profile pictures" as an indication that they were more satisfied with their relationship (Saslow et al. 2012: 411), or to use official status updates to introduce more certainty into a new relationship (Fox et al. 2013: 771). As opposed to user-generated dictionary entries and forum discussions by ordinary users above, the content these couples post about their monthsaries are more likely to include conspicuous consumption as they brand themselves or incorporate sponsorship into their self-presentation. In other words, these microcelebrity couples present exaggerated PDAs that "present their relationship in its most idealized form" to "affir[m] superiority" and to "sell the product of a loving authentic relationship" (Mod 2010: 70); they serve as extreme examples in which the materialism and visibility of monthsary practices are more pronounced and intentional than ordinary couples.

Instagram was selected as the primary medium for this exploratory study given its prominence among users in Singapore (Abidin 2014, Aw Yeong 2013), and among informants in my larger project on social media branding (Abidin 2014, Abidin 2015b). Although all three couples now in their twenties, they each began dating in their teenage years and were among each others' first few partners, thus constituting what I earlier define as “young coupling”. Kelly \& Tony, Nicole \& Kevin, and Maggie \& Nathan each curate a couple hashtag on Instagram that archives images portraying their relationship in action, as an act of couple-branding (Abidin 2015c). In the interest of maintaining the couples' pseudonymity, hashtags and images will be omitted from this paper and replaced with summaries from fieldnotes of thick description (Geertz 1973).

\section{Kelly \& Tony}

Kelly \& Tony are in their mid-twenties and have been dating for over eight years. They met in secondary school and are each other's first romantic partners - neither had ever dated anyone else prior to their relationship. In Instagram images of their monthsaries, more generic hashtags such as "monthsary" and "monthsary celebration" are used in addition to their couple hashtag. Kelly \& Tony also hashtag numerically significant or auspicious monthsaries such as their 70th, 77th, 80th, 88th, and 90th monthsaries. On these particularly significant monthsaries, the couple tended to go for short trips in the South East Asian region including Bangkok, Bali, and Taipei. Instagram images of their monthsaries abroad featured selfies of the couple at various landmarks, and in transient 
but intimate rooming situations such as rose petals on a queen-sized bed and bubble baths, since the couple do not live together - in Singapore, the norm is for young people to live in their parental home until marriage to a fellow Singaporean qualifies them to purchase government flats from the Housing Development Board - and presumably have few opportunities to be alone and intimate.

The composition and caption of their monthsary posts had two notable characteristics: The first characteristic was the renarrativization of history and memory, with both Kelly \& Tony often waxing nostalgia over "how young" they were when they first met, and how their dating practices have shifted - "haha we used to make so much effort for monthsaries but now we are lazy like shit”. However, it is not immediately clear that the couple's efforts at maintaining monthsaries have dwindled given the evidently effortful overseas celebration plans they regularly hold.

The second characteristic was the emphasis on peer affirmation, or a form of "peersupervision" (Jackson et al. 2011: 631) with both parties recounting how their "old friends" have watched them "grow as a couple", and how "all their close friends" could testify to how "crazy fun", "solid”, or "long-lasting” their relationship was. These sentiments were usually accompanied by images of Kelly \& Tony spending time with their fellow couple friends (usually on double- or triple-dates) at eateries or house parties.

\section{Nicole \& Kevin}

Nicole \& Kevin are in their early-twenties and have been dating for over four years. They met in university and each dated three or four partners prior to this relationship - the ambivalence is noted as Nicole sometimes negotiates on her blog whether or not her past relationships during her younger teenage years were mere "puppy love" and considered "not serious" or "unofficial". The couple have almost continuously commemorated over 50 monthsaries, with a handful of exceptions when they had brief breakups. In each Instagram monthsary post, they publicize details of their celebrations by hashtagging the venue of their celebrations and notable consumptions such as expensive wine, gourmet dining, and branded luxury gifts. On some monthsaries, Nicole \& Kevin's gifts to each other were personalized 'his \& her' items baring their names or animated illustrations in the couple's likeness. Additionally, several of their monthsaries were commemorated through specially organized 'couple' photoshoots, in which Nicole \& Kevin dressed up in sharp outfits at various venues (i.e. hotel staycations, night time city scenery, tourist destinations in Singapore) and posed for photographs as gifts to each other.

The composition and caption of their monthsary posts had two notable characteristics: The first characteristic was the hyper-visibility of their coupling for security, with both parties repeatedly affirming how they were unabashed about PDA - "people were staring at us like we were crazy, but we were in love so we didn't care”. Nicole \& Kevin also tended to emphasize that they were "unlike other couples" who did not invest in monthsaries as they did, and often implied that their practices affirmed a sense of 
exclusivity (Dillow et al. 2014: 105, Rubin 1970) and superiority of their coupling over other couples.

The second characteristic was the continuous remaking and remarking of themselves as a pseudo-family unit separate from their families of origin. Despite the occasional Instagram image of Nicole \& Kevin spending time with each other's family such as parents and siblings (and home countries - Singapore and the US), the couple constantly attempts to public mark and normalize their premarital coupling through monthsaries as rituals to signify the status of their relationship. These involved archiving "symbolic activities" during monthsaries to signify their "relationship status and expectations" (Jackson et al. 2011: 630, drawing on Greer \& Buss 1994, Hendrick et al. 1988), such as their intermittent cohabitation in Singapore, and making exceptional the usually mundane domestic chores engaged in by married couples such as grocery shopping and sharing the laundry. Nicole \& Kevin also tended to reiterated that they felt like "an old married couple”. Nicole \& Kevin's monthsaries seem simultaneously extravagant and ordinary in that they toggle between luxurious celebrations and the humdrum of everyday life. However, both ends of the spectrum congruently display their desire to publicize, and indeed stabilize, the state of their coupling in the absence of any formal martial status.

\section{Maggie \& Nathan}

Maggie \& Nathan are in their late-twenties and have been dating for over seven years. They met in vocational school and are each other's first romantic partners. On first look, their monthsaries seem indistinguishable from other Instagram images featuring the couple in mundane settings such as having dinner in one of their homes, or remembering a day of colour-coordinated outfits. The only hint of extravagance of any sort are the occasional hand bouquets that Maggie conscientiously photographs and archives on their hashtags, gifted to her by Nathan during numerically significant or auspicious monthsaries.

The composition and caption of their monthsary posts had two notable characteristics: The first characteristic was the simplicity of their monthsary celebrations, in which Nathan might give Maggie a lift to work, Maggie might spend her lunch break with Nathan, or both parties might meet up for a movie after work - "monthsaries don't have to be special if we love each other wholeheartedly everyday". While the couple seemed to imply that their monthsary practices were no different than their everyday dating (i.e. "dressing up to go out to dinner, going to the movies or theatre, and giving or receiving gifts”; see Jackson et al. 2011: 632), their monthsary dates were regularly commemorated on Instagram with their couple hashtag, thus implying that Maggie \& Nathan placed least some significance placed on the ritual of monthsaries.

The second characteristic was the future orientation of their monthsary posts, in which the couple projected milestones and their future lives together. These aspirational practices are not uncommon among both ordinary and microcelebrity couples who practice monthsaries. On some monthsaries, Maggie would lift (and credit) an image from 
Pinterest as a snapshot of how her future coupling with Nathan might look like. This included wedding dresses, interior décor of homes, and honeymoon venues. In his captions, Nathan would post forward-looking sentiments in a similar vein such as "looking forward to many month monthsaries with you!” Maggie has also suggested that she would love for her wedding to take place on a monthsary, so that the date would be "extra significant" and "memorable” for them. Thus, rituals such as monthsaries become a mechanism for couples like Maggie \& Nathan to display their coupling values in beliefs (Geertz 1973), which in this example, is focused on a future-oriented imagining of more significant relationship milestones to come, as opposed to the present-oriented, consumption-based celebrations untaken by Kelly \& Tony and Nicole \& Kevin.

\section{Happy \#monthsary babe!}

Studies of young couples' self-presentation of their romantic relationship on social media have largely been dominated by psychologists (Fox \& Warber 2013; Fox \& Warber 2014; Fox et al. 2013; Papp et al. 2012; Saslow et al. 2012) and social scientists (Mod 2010; Rueda et al. 2015) focusing on Facebook. While this paper is similarly interested in the new forms of communication afforded by the proliferation of digital media and selfbranding on social media, it takes interest in the romantic ritual of monthsaries celebrated by young couplings. As a repeatedly constructed, mutually communicative process that is outward oriented as a Public Display of Affection, monthsaries symbolize minimilestones, cynical brevity, commitment affirmation, exceptional gifting, gendered expectancies, and celebratory excess.

As romantic interpersonal relationships are being increasingly enacted and archived on social media and the internet (Fox \& Warber 2014, Sprecher 2010), this paper turns to the short history of monthsaries through internet folklore and prolific microcelebrity couples to understand why and how these rituals are enacted, and the affirmation and backlash towards the practice. As intentional displays of an intimately private union in public physical and digital spaces, monthsaries are one form of public domesticity that couples conscientiously calibrate to communicate their self-identity and self-branding. Contextualized understandings via an early Singapore internet space reveal that monthsaries are 1) Mini-milestones are only significant to early couplings, first couplings, or at memorable intervals; 2) Cynical brevity is inauspicious and pre-empts precarity; 3) Commitment affirmation changes in form as couplings progress; 4) Exceptional gifting is unnecessary expenditure; 5) Gendered expectancies are a male burden; and 6) Celebratory excess loses meaning from saturation fatigue. Case studies of three Singaporean microcelebrity couples on Instagram were presented as exceptional and hyper-conspicuous enactments of monthsaries, in which couple self-identity and selfbranding were taken to the extreme.

In the final section, I surveyed the visual displays of monthsaries through dating scripts generated on Instagram by three microcelebrity couples in Singapore. Kelly \& Tony’s monthsaries focused on overseas travels, intimate rooming setups, and couple friendships. 
They renarrativized the history and memory of their relationship, and emphasized a peer affirmation of their coupling. Nicole \& Kevin's monthsaries focused on luxurious consumables, professional photoshoots, and publicity. They hyper-visibilized their coupling for a sense of elevated security, and continuously remade and remarked themselves as a pseudo-family unit separate from their families of origin. Maggie \& Nathan's monthsaries were embedded into the rhythm of everyday routines, and focused on the prospects of their lives together. They simplified their monthsary celebrations, and oriented posts to be possible projections of their future milestones.

Future studies may explore vernacular renderings of monthsaries in various localized contexts, compare courtship rituals between monthsaries and anniversaries, investigate the visual displays of monthsaries on various image-oriented social media such as Tumblr and Pinterest, analyse gendered enactments of monthsaries between male and female partners, and across heterosexual and homosexual partners.

\section{References}

Abidin, C. (2014) '\#In\$tagLam: Instagram as a repository of taste, a brimming marketplace, a war of eyeballs', in M. Berry and M. Schleser (eds), Mobile Media Making in the Age of Smartphones, New York, US: Palgrave Pivot, pp. 119-128

Abidin, C. (2015) 'Aspirational tensions: Young couples and homemaking in a tightly regulated ecology', Oral presentation given at Moral Horizons, Australian Anthropological Society (AAS) Conference 2015, University of Melbourne, Melbourne. Dec 3, 2015.

Abidin, C. (2015b) 'Please subscribe! Influencers, social media, and the commodification of everyday life', (Unpublished doctoral dissertation), University of Western Australia, Perth, Australia.

Abidin, C. (2015c) 'Public coupling: Imageries of domestic intimacy among social media microcelebrities', Oral presentation given at Digital Ethnography Research Centre (DERC) Seminar, Royal Melbourne Institute of Technology (RMIT), Melbourne. May 13, 2015.

Ang, S. H. (1997) 'Chinese consumers' perception of alpha-numeric brand names', Journal of Consumer Marketing 14, 3, 220-233

Areni, C. S., Kiecker, P., \& Palan, K. M. (1998) 'Is it better to give than to receive? Exploring gender differences in the meaning of memorable gifts', Psychology \& Marketing 15, 81-109.

Aw Yeong, B. (2013) 'Instagram is fastest growing media application among mobilesavvy users here', The New Paper, September 1. Available at http://www.tnp.sg/content/instagram-fastest-growing-media-application- amongmobile-savvy-users-here. Accessed 15 January 2014.

Bailey, B. L. (1989) From front porch to back seat: Courtship in twentieth-century America, Baltimore, MD: Johns Hopkins University Press

Baxter, L. A. (1987) 'Symbols of relationship identity in relationship cultures', Journal of Social and Personal Relationships 4, 261-280

Baxter, L. A., \& Braithwaite, D. O. (2006) 'Family rituals', in L. H. Turner and R. West (eds), The family communication sourcebook, Thousand Oaks, CA: Sage, pp. 259-280 
Bruess, C. J. S., \& Pearson, J. C. (1997) 'Interpersonal rituals in marriage and adult friendship', Communication Monographs 64, 25-46

Campbell, K., \& Ponzetti Jr. J. J. (2007) 'The moderating effects of rituals on commitment in premarital involvements', Sexual and Relationship Therapy 22, 415-428

Cate, R. M., \& Lloyd, S. A. (1992) Courtship, Newbury Park, CA: SAGE

Coyne, S. M., Stockdale, L., Busby, D., Iverson, B., \& Grant, D. M. (2011) “I luv u :)!”: A Descriptive Study of the Media Use of Individual in Romantic Relationships', Family Relations 60, 2, 150-162

Dillow, M. R., Goodboy, A. K., \& Bolkan, S. (2014) 'Attachment and the Expression of Affection in Romantic Relationships: The Mediating Role of Romantic Love', Communication Reports 27, 2, 102-115

Forbes, D. (1993) 'Singlish', English Today 9, 2, 18-22

Fox, J., \& Warber, K. M. (2013) 'Romantic Relationship Development in the Age of Facebook: An Exploring Study of Emerging Adults' Perceptions, Motives, and Behaviors', Cyberpsychology, Behavior, Social Networking 16, 1, 3-7

Fox, J., Warber, K. M., \& Makstaller, D. C. (2013) 'The role of Facebook in romantic relationship development: An exploration of Knapp's relational stage model', Journal of Social and Personal Relationships 30, 6, 771-794

Fox, J., \& Warber, K. M. (2014) 'Social networking sites in romantic relationships: Attachment, uncertainty, and partner surveillance on Facebook', Cyberpsychology, Behaviour, and Social Networking 17, 1, 3-7

Geertz, C. (1973) The interpretation of cultures: selected essays, New York: Basic Books

Glaser, B. G. (1978) Theoretical sensitivity: advances in the methodology of grounded theory, Mill Valley, Calif: Sociology Press

Gouldner, A. W. (1960) 'The norm of reciprocity', American Sociological Review 25, 161178

Greer, A. E., \& Buss, D. M. (1994) 'Tactics for promoting sexual encounters', Journal of Sex Research 31, 185-201

Hendrick, S. S., Hendrick, C., \& Adler, N. L. (1988) 'Romantic relationships: Love, satisfaction, and staying together', Journal of Personality and Social Psychology 54, 980988

Jackson, P. B., Kleiner, S., Geist, C., \& Cebulko, K. (2011) 'Conventions of courtship: Gender and race differences in the significance of dating rituals', Journal of Family Issues $32,5,629-652$

Knox, D., \& Wilson, K. (1981) 'Dating behaviors of university students', Family Relations 30, 255-258

Laner, M. R., \& Ventrone, N. A. (2000) 'Dating scripts revisited', Journal of Family Issues $21,488-500$

Levi-Strauss, C. (1969) The elementary structures of kinship, Boston, MA: Beacon Press.

Malinowski, B. (1922) Argonauts of the Western Pacific, London, England: Routledge \& Kegan Paul

Manning, W. D., \& Smock, P. J. (2005) 'Measuring and modeling cohabitation: New perspectives from qualitative data', Journal of Marriage and Family 67, 989-1002 
Merriam-Webster. (2015) 'Monthsary', Merriam-Webster Online Dictionary. Available at http://nws.merriam-

webster.com/opendictionary/newword display alpha.php?letter=Mo\&last=120. Accessed 5 December 2015.

Mod, G. B. B. A. (2010) 'Reading romance: The impact Facebook rituals can have on a romantic relationship', Journal of Comparative Research in Anthropology and Sociology $1,2,61-77$

Ong, W. (1982) Orality and Literacy: The Technologizing of the Word, London: Methuen \& Co. Ltd

Oring, E. (1984) 'Dyadic traditions', Journal of Folklore Research 21, 19-28

Papp, L. M., Danielewicz, J., \& Cayemberg, C. (2012) “'Are We Facebook Official?" Implications of Dating Partners' Facebook Use and Profiles for Intimate Relationship Satisfaction', Cyberpsychology, Behavior, and Social Networking 15, 2, 85-90

Pearson, J. C., Child, J. T., \& Carmon, A. F. (2011) 'Rituals in Dating Relationships: The Development and Validation of a Measure', Communication Quarterly 59, 3, 359-379

Rueda, H. A., Lindsay, M. \& Williams, L. R. (2015) "'She posted It on Facebook": Mexican American Adolescents' Experiences With Technology and Romantic Relationship Conflict', Journal of Adolescent Research 30, 4, 419-445

Rubin, Z. (1970) 'Measurement of romantic love', Journal of Personality and Social Psychology 16, 265-273

Saslow, L. R., Muise, A., Impett, E. A., \& Dubin, M. (2012) 'Can You See How Happy We Are? Facebook Images and Relationship Satisfaction', Social Psychology and Personality Science 4, 4, 411-418

Senft, T. M. (2008) Camgirls: Celebrity and Community in the Age of Social Networks, New York: Peter Lang

sgclub.com. (2015a) 'Monthsary', sgclub.com. Available at http://forums.sgclub.com/singapore/monthsary 401875.html. Accessed 5 December 2015.

sgclub.com. (2015b) 'WHY SGCLUB.COM?', sgclub.com. Available at http://www.sgclub.com/about/. Accessed 19 July 2016.

Sprecher, S. (2010) 'The influence of social networks on romantic relationships: through the lens of the social network', Personal Relationships 17, 1-15

Urban Dictionary. (2015a) 'Monthsary', Urban Dictionary. Available at http://www.urbandictionary.com/define.php?term=monthsary. Accessed 5 December 2015.

Urban Dictionary. (2015b) 'Monthiversary', Urban Dictionary. Available at http://www.urbandictionary.com/define.php?term=Monthiversary. Accessed 5 December 2015.

Urban Dictionary. (2015d) 'Moniversary', Urban Dictionary. Available at http://www.urbandictionary.com/define.php?term=moniversary. Accessed 5 December 2015.

Urban Dictionary. (2015e) 'Menthuversary', Urban Dictionary. Available at http://www.urbandictionary.com/define.php?term=menthuversary. Accessed 5 December 2015.

Waller, W. W. (1937) 'The rating and dating complex', American Sociological Review 2, 727-734 
YourSingapore. (2015) 'Faces of Singapore', YourSingapore. Available at http://www.yoursingapore.com/about-singapore/people-of-singapore.html. Accessed 5 December 2015.

Zappavigna, M. (2012) The discourse of Twitter and social media, London: Continuum.

Crystal Abidin is anthropologist and ethnographer. She researches young people's relationships with social media, the internet, and technology. Her latest project looks at public domesticity among East Asian couples, and power coupling as a form of digital practice. Crystal is presently a Postdoctoral Fellow in the Department of Sociology, National University of Singapore, and an Affiliated Researcher with the Media Management and Transformation Centre, Jonkoping University. Reach her at wishcrys.com.

Email: crystalabidin@gmail.com 